\title{
Streptomyces cheonanensis sp. nov., a novel streptomycete with antifungal activity
}

\author{
Hyo Jin Kim, Sung Chul Lee and Byung Kook Hwang \\ Laboratory of Molecular Plant Pathology, College of Life and Environmental Sciences, Korea \\ University, Seoul 136-713, Korea
}

Correspondence

Byung Kook Hwang

bkhwang@korea.ac.kr

\begin{abstract}
Actinomycete strain $\mathrm{VC}-\mathrm{A} 46^{\top}$, which exhibits antifungal activity, was isolated from a soil sample collected from Cheonan, Korea. The strain was determined to belong to the genus Streptomyces, based on its morphological and chemotaxonomic characteristics. The cell wall of this strain contained LL-diaminopimelic acid. The predominant fatty acids were iso- $\mathrm{C}_{16: 0}, \mathrm{C}_{16: 0}$ and $\mathrm{C}_{16: 1}$ cis 9. The DNA G $+\mathrm{C}$ content of strain VC-A $46^{\top}$ was 75.5 mol\%. Phylogenetic analysis of the $16 \mathrm{~S}$ rRNA gene sequence of this strain revealed that it differed from those of the described streptomycetes available in public databases. Analyses of DNA-DNA relatedness data, together with data regarding the strain's morphological, physiological and biochemical characteristics, also confirmed that this strain constitutes a novel Streptomyces taxon, which is distinguishable from closely related reference strains. Therefore, it is proposed that strain VC-A $46^{\top}(=\mathrm{KCCM}$ $42119^{\top}=$ NBRC $\left.100940^{\top}\right)$ represents the type strain of a novel species, named Streptomyces cheonanensis sp. nov.
\end{abstract}

The genus Streptomyces was initially introduced by Waksman \& Henrici (1943) as a term to encompass aerobic, spore-forming actinomycetes. Streptomycetes are used extensively in industry, due to their ability to generate a number of chemical compounds, including antibiotics, enzymes, enzyme inhibitors, antitumour agents and antifungal compounds (Chun et al., 1997; Kim \& Hwang, 2003). In particular, Streptomyces species are prolific producers of structurally diverse antibiotics. Most of the antibiotics developed for agricultural uses, including pesticides, were isolated from Streptomyces strains (Tanaka \& Ōmura, 1993). Among antifungal antibiotics discovered in recent years from Streptomyces strains, polyketide-spiroketal spirofungins, macrolide cineromycins, oligomycin A, antimycin-type kitamycins, aflatoxin inhibitor aflastatins, aminoacetophenone family heptaene antibiotics and novel nikkomycin analogues were found to have potent activity (Kim \& Hwang, 2003).

In the present study, we isolated strain $\mathrm{VC}-\mathrm{A} 46^{\mathrm{T}}$ from the soil of a radish field in Cheonan, Korea (Lee \& Hwang,

Published online ahead of print on 13 October 2005 as DOI 10.1099/ ijs.0.63816-0.

Abbreviations: ISP, International Streptomyces Project.

The GenBank/EMBL/DDBJ accession number for the $16 S$ rRNA gene sequence of S. cheonanensis VC-A $46^{\top}$ is AY822606.

A scanning electron micrograph, a $\gamma$-region-based neighbour-joining tree and details of the fatty acid content analysis and DNA-DNA hybridization experiments are available as supplementary material in IJSEM Online.
2002). Strain VC-A $46^{\mathrm{T}}$ exhibited antifungal activity against the plant-pathogenic fungi Alternaria mali, Colletotrichum orbiculare, Magnaporthe grisea, Fusarium oxysporum f. sp. lycopersici and Rhizoctonia solani and antioomycete activity against Phytophthora capsici (data not shown). Morphological, physiological, biochemical, phylogenetic and molecular evidence was obtained and analysed in our identification of strain VC-A $46^{\mathrm{T}}$.

The soil suspension from a soil sample from Cheonan was seeded on a humic acid/vitamin agar medium and was subsequently incubated for 14 days at $28^{\circ} \mathrm{C}$. The reference strains Streptomyces thermolineatus KCCM $41146^{\mathrm{T}}$, Streptomyces macrosporus KCCM $41250^{\mathrm{T}}$, 'Streptomyces cattleya' KCCM 11825, Streptomyces acidiscabies KCCM $41240^{\mathrm{T}}$ and Streptomyces megasporus KCCM $41251^{\mathrm{T}}$ were provided from the Korean Culture Center of Microorganisms, Seoul, Korea. Strain VC-A $46^{\mathrm{T}}$ and the reference strains were grown on a yeast extract/malt extract agar medium (4 g yeast extract, $10 \mathrm{~g}$ malt extract, $4 \mathrm{~g}$ glucose, $15 \mathrm{~g}$ agar, 11 water) at $28{ }^{\circ} \mathrm{C}$ and stored in $15 \%$ glycerol at $-70{ }^{\circ} \mathrm{C}$.

The morphological characteristics of strain $\mathrm{VC}-\mathrm{A} 46^{\mathrm{T}}$, including spore chain morphology, spore size and surface ornamentation, were assessed by light and scanning electron microscopy (SEM) of 14-day-old cultures on yeast extract/ malt extract (ISP 2) agar (Williams \& Davies, 1967). Aerial spore-mass colour, substrate mycelium pigmentation and colouration of the diffusible pigments of strain $\mathrm{VC}-\mathrm{A} 46^{\mathrm{T}}$ were recorded on ISP (International Streptomyces Project) media (Shirling \& Gottlieb, 1966) and as described by Locci 
(1989). The biochemical and physiological characteristics of strain VC-A46 ${ }^{\mathrm{T}}$ were determined according to the methods described by Shirling \& Gottlieb (1966), Williams et al. (1983) and Locci (1989).

For chemical analyses, biomass from strain $\mathrm{VC}-\mathrm{A} 46^{\mathrm{T}}$ was prepared by culturing in yeast extract/malt extract broth (4 g yeast extract, $10 \mathrm{~g}$ malt extract, $4 \mathrm{~g}$ glucose, 11 water) for 4 days at $28^{\circ} \mathrm{C}$ in a rotary shaker $(120$ r.p.m.) and harvested by centrifugation. The harvested cells were washed with methanol and water. Freeze-dried cells $(20 \mathrm{mg})$ were then hydrolysed with $5 \mathrm{ml} 6 \mathrm{M} \mathrm{HCl}$ at $100^{\circ} \mathrm{C}$ for $18 \mathrm{~h}$. The filtrate was evaporated to remove the remaining $\mathrm{HCl}$. The isomer type of the diaminopimelic acid in the peptidoglycan layer was determined by TLC (Lee et al., 2005), using a modified solvent system of methanol/water/10 M HCl/ pyridine $(80: 26: 2 \cdot 5: 20$, by vol.) (Becker et al., 1965), followed by ninhydrin staining $(0 \cdot 1 \% \mathrm{w} / \mathrm{v}$ ninhydrin in acetone). Cellular fatty acids were then prepared and analysed according to the method described by Guckert et al. (1991).

We analysed the $\mathrm{G}+\mathrm{C}$ content of strain $\mathrm{VC}-\mathrm{A} 46^{\mathrm{T}}$ using the thermal melting method pioneered by Marmur \& Doty (1962), Mandel et al. (1970) and Johnson (1985). Strain VC$\mathrm{A} 46^{\mathrm{T}}$ was inoculated into yeast extract/malt extract broth, followed by DNA extraction (150-250 $\left.\mathrm{g} \mathrm{ml}^{-1}\right)$. A $1 /$ 10 volume of $8 \mathrm{M} \mathrm{LiCl}$ and 2 vols ethanol were then added to the DNA extracts. After five washes with $70 \%$ ethanol, the remaining DNA was dissolved in $500 \mu \mathrm{l} 0 \cdot 1 \times$ SSC. The DNA was quantitatively analysed using a spectrophotometer (DU-650; Beckman) and the melting temperature was measured with a UV/visible spectrophotometer (Ultraspec 2000; Pharmacia Biotech).

Strain VC-A $46^{\mathrm{T}}$ was cultured on ISP 2 agar for 4 days at $28^{\circ} \mathrm{C}$ and picked colonies were then cultured in LB broth $(10 \mathrm{~g} \mathrm{NaCl}, 10 \mathrm{~g}$ tryptone and $5 \mathrm{~g}$ yeast extract in 11 water) in a rotary shaker for 2 days at $28^{\circ} \mathrm{C}$. Genomic DNA was isolated from cultured cells according to the method described by Pospiech \& Neumann (1995). The 16S rRNA gene of strain VC-A $46^{\mathrm{T}}$ was then amplified by PCR, using two universal bacterial primers, FD1 (5'-AGAGTTTGATCCTGGG-3') and RP2 (5'-ACGGCTACCTTGTTACGACTT-3') (Weisburg et al., 1991). These primer-based PCR amplifications were conducted on a PTC-200 thermal cycler (MJ Research). The samples were subjected to an initial denaturing step, for $4 \mathrm{~min}$ at $94^{\circ} \mathrm{C}$. The thermal profile comprised 25 cycles, consisting of 1 min denaturation at $98^{\circ} \mathrm{C}, 1 \mathrm{~min}$ annealing at $57^{\circ} \mathrm{C}$ and 2 min extension at $72^{\circ} \mathrm{C}$. Finally, a 3 min extension step at $72{ }^{\circ} \mathrm{C}$ and a final cooling to $4{ }^{\circ} \mathrm{C}$ completed the reaction sequence. PCR products were purified from $1 \%$ agarose gel ( $\mathrm{Wu}$ et al., 1997), ligated into the pCR 2.1-TOPO T vector (Invitrogen) and transformed into Escherichia coli TOP10 cells (Invitrogen) by electroporation. The purified PCR products were then sequenced on an ABI 310 automatic DNA sequencer (Applied Biosystems) using Big Dye terminator cycle sequencing ready reaction kits (PE Applied
Biosystems). 16S rRNA gene sequence analysis was then conducted using the BLAST network services provided by the NCBI (Altschul et al., 1997) and the DNASTAR program, version 4.0 (DNASTAR). These sequences were also compared to the public nucleotide databases, using the BLAST algorithm, to identify $16 \mathrm{~S}$ rRNA gene sequences with high degrees of similarity. The almost-complete $16 \mathrm{~S}$ rRNA gene sequence of strain $\mathrm{VC}-\mathrm{A} 46^{\mathrm{T}}$ was aligned with representative sequences of related streptomycete species in the GenBank database (NCBI). Sequences were edited with the DNASTAR (Lasergene system for sequence analysis) computer package. Alignment was performed with the CLUSTAL $\mathrm{W}$ program (Thompson et al., 1994). PAUP version 4.0b10 (Swofford, 2002) software was used to carry out the phylogenetic analyses. The resultant data were then examined using the maximum-parsimony method (Fitch, 1971) and the neighbour-joining method (Saitou \& Nei, 1987). The topology of the resultant unrooted tree was evaluated by bootstrap assay of the neighbour-joining tree, performed in 1000 replications. Phylogenetic tree display, editing and printing were carried out using the TreeView program, version 1.6.6 (Page, 1996).

DNA-DNA hybridization experiments with strain VC-A46 ${ }^{\mathrm{T}}$ and the reference strains $S$. thermolineatus DSM $41451^{\mathrm{T}}, S$. macrosporus DSM $41449^{\mathrm{T}}$, 'S. cattleya' JCM 4925 and $S$. acidiscabies ATCC $49003^{\mathrm{T}}$ were performed according to the methods described by Chung et al. (1999). DNA probes were labelled with a Dig-High prime kit (Boehringer Mannheim). Hybridization was then performed on nylon membranes (Hybond-N ${ }^{+}$; Amersham Pharmacia Biotech).

Strain VC-A46 ${ }^{\mathrm{T}}$ was observed to grow well on a variety of ISP agar media, including ISP 2, oatmeal agar (ISP 3), inorganic salts/starch agar (ISP 4), peptone/yeast extract agar (ISP 6) and tyrosine agar (ISP 7) (Shirling \& Gottlieb, 1966). Aerial mycelium of strain VC-A $46^{\mathrm{T}}$ was abundant on ISP 3 agar. The aerial mycelium was grey to white in colour and the substrate mycelium was light yellow on ISP 4. Diffusible pigments and melanin were generated on most ISP media. A scanning electron micrograph of the spore chains of strain VC-A46 ${ }^{\mathrm{T}}$ can be viewed as Supplementary Fig. S1 in IJSEM Online. Strain VC-A $46^{\mathrm{T}}$ is characterized by short or long spore chains with soft surfaces. Spores were elliptical in shape and $0.8 \mu \mathrm{m}$ in length. The morphological, physiological and biochemical characteristics of strain VCA $46^{\mathrm{T}}$ and phylogenetically related Streptomyces species are shown in Table 1.

The DNA G $+\mathrm{C}$ content of strain $\mathrm{VC}-\mathrm{A} 46^{\mathrm{T}}$ was $75 \cdot 5 \mathrm{~mol} \%$. Strain VC-A $46^{\mathrm{T}}$ was also found to contain LL-diaminopimelic acid in the peptidoglycan of its cell walls, thereby indicating that strain VC-A $46^{\mathrm{T}}$ exhibits cell-wall chemotype I (Lechevalier \& Lechevalier, 1970). The fatty acid composition of strain VC-A46 ${ }^{\mathrm{T}}$ is shown in Supplementary Table S1 in IJSEM Online. The predominant cellular fatty acids found included 14-methylpentadecanoic acid (iso$\left.\mathrm{C}_{16: 0}\right)$, hexadecanoic acid $\left(\mathrm{C}_{16: 0}\right)$ and cis-9-hexadecenoic acid $\left(\mathrm{C}_{16: 1}\right.$ cis 9$)$. 
Table 1. Morphological, physiological and biochemical characteristics of strain $\mathrm{VC}-\mathrm{A} 46^{\top}$ and phylogenetically related Streptomyces species

Strains: 1, VC-A46 ${ }^{\mathrm{T}}$; 2, S. thermolineatus DSM 41451 $1^{\mathrm{T}}$; 3 , 'S. cattleya' JCM 4925; 4, S. macrosporus DSM $41449^{\mathrm{T}}$; 5, S. megasporus DSM $41476^{\mathrm{T}}$. None of the strains grow at $4{ }^{\circ} \mathrm{C}$. All of the strains degrade gelatin, are susceptible to neomycin $\left(50 \mu \mathrm{g} \mathrm{ml}^{-1}\right)$ and rifampicin $\left(50 \mu \mathrm{g} \mathrm{ml}^{-1}\right)$, grow on L-cysteine, L-histidine and L-valine $(0 \cdot 1 \%, \mathrm{w} / \mathrm{v})$ as sole nitrogen sources and grow on fructose, L-rhamnose and xylose $(1 \%, \mathrm{w} / \mathrm{v})$ as sole carbon sources. +, Positive; -, negative; ?, result uncertain; ND, no data.

\begin{tabular}{|c|c|c|c|c|c|}
\hline Characteristic & 1 & 2 & 3 & 4 & 5 \\
\hline Spore chain morphology ${ }^{*}$ & RF & RF & SP & $\mathrm{RF}$ & $\mathrm{ND}$ \\
\hline Aerial hyphae & + & + & + & - & + \\
\hline Melanin production & + & - & - & - & - \\
\hline Maximum $\mathrm{NaCl}$ tolerance $(\%, \mathrm{w} / \mathrm{v})$ & 7 & 6 & 3 & 6 & ND \\
\hline \multicolumn{6}{|l|}{ Colour of spore mass/substrate mycelium on: $\dagger$} \\
\hline ISP medium 2 & $\mathrm{PY} / \mathrm{PY}$ & WG/PY & $\mathrm{OP} / \mathrm{PY}$ & None/PY & $\mathrm{W} / \mathrm{PY}$ \\
\hline ISP medium 3 & $\mathrm{G} / \mathrm{O}$ & $\mathrm{W} / \mathrm{W}$ & $\mathrm{OP} / \mathrm{PY}$ & None/PY & W/OW \\
\hline ISP medium 4 & GW/PY & WG/PY & OS/PY & ND & w/ow \\
\hline ISP medium 5 & $\mathrm{O} / \mathrm{O}$ & WG/PY & OS/PY & ND & $\mathrm{W} / \mathrm{PY}$ \\
\hline ISP medium 6 & GW/VY & $\mathrm{W} / \mathrm{PY}$ & None/PY & $\mathrm{ND}$ & $\mathrm{W} / \mathrm{PY}$ \\
\hline ISP medium 7 & $\mathrm{GW} / \mathrm{W}$ & WG/PY & OS/PY & $\mathrm{ND}$ & GW/OW \\
\hline \multicolumn{6}{|l|}{ Colour of soluble pigment on: } \\
\hline ISP medium 3 & DG & None & None & None & None \\
\hline ISP medium 5 & $\mathrm{O}$ & None & None & $\mathrm{ND}$ & None \\
\hline ISP medium 6 & None & None & SB & ND & SB \\
\hline ISP medium 7 & BW & None & None & $\mathrm{ND}$ & G \\
\hline \multicolumn{6}{|l|}{ Degradation of: } \\
\hline Aesculin & + & - & - & + & - \\
\hline Starch & + & + & - & + & + \\
\hline Resistance to oleandomycin $\left(100 \mu \mathrm{g} \mathrm{ml}^{-1}\right)$ & - & - & - & - & + \\
\hline \multicolumn{6}{|l|}{ Growth at/in: } \\
\hline $45^{\circ} \mathrm{C}$ & - & + & + & + & + \\
\hline $\mathrm{pH} 5$ & - & - & + & - & - \\
\hline $\mathrm{pH} 11$ & - & + & + & + & - \\
\hline $\begin{array}{l}\text { Growth on DL- } \alpha \text {-amino-n-butyric acid as sole } \\
\text { nitrogen source }(0 \cdot 1 \%, \mathrm{w} / \mathrm{v})\end{array}$ & + & + & + & + & - \\
\hline \multicolumn{6}{|l|}{ Growth on sole carbon sources $(1 \%, \mathrm{w} / \mathrm{v})$ : } \\
\hline Adonitol & + & + & + & + & $?$ \\
\hline Raffinose & + & - & - & - & - \\
\hline \multicolumn{6}{|l|}{ Antibiosis against: } \\
\hline Bacillus subtilis NCIMB $3610^{\mathrm{T}}$ & + & + & - & - & - \\
\hline Micrococcus luteus NCIMB 196 & + & + & + & + & - \\
\hline Saccharomyces cerevisiae CBS 1171 & + & - & + & + & - \\
\hline Streptomyces murinus ISP $5091^{\mathrm{T}}$ & + & - & + & + & - \\
\hline
\end{tabular}

${ }^{\star}$ RF, Rectiflexibiles; SP, Spirales.

$\dagger \mathrm{BW}$, Brown to white; DG, dark grey; G, grey; GW, grey to white; O, olive; OP, orchid mixed with pinkish white; OS, orchid mixed with some white; OW, oyster white; PY, pale yellow; SB, slight browning; VY, violet to yellow; w, white; WG, white to grey.

Comparison of the nearly complete $16 \mathrm{~S}$ rRNA gene sequence (1527 nt) of strain VC-A $46^{\mathrm{T}}$ with previously obtained sequences of Streptomyces species deposited in GenBank (NCBI) indicated that this organism is related phylogenetically to members of the genus Streptomyces. The rooted phylogenetic tree (Fig. 1) based on the neighbour-joining method indicated that strain $\mathrm{VC}-\mathrm{A} 46^{\mathrm{T}}$ formed a distinct branch with the proposed type strain of ' $S$. cattleya' and the type strains of $S$. thermolineatus and S. macrosporus. Strain VC-A $46^{\mathrm{T}}$ exhibited $95 \cdot 9 \%$ similarity to ' $S$. cattleya' JCM 4925 (56 nucleotide differences at 1354 sites), $95 \cdot 4 \%(62 / 1354)$ similarity to $S$. thermolineatus DSM 


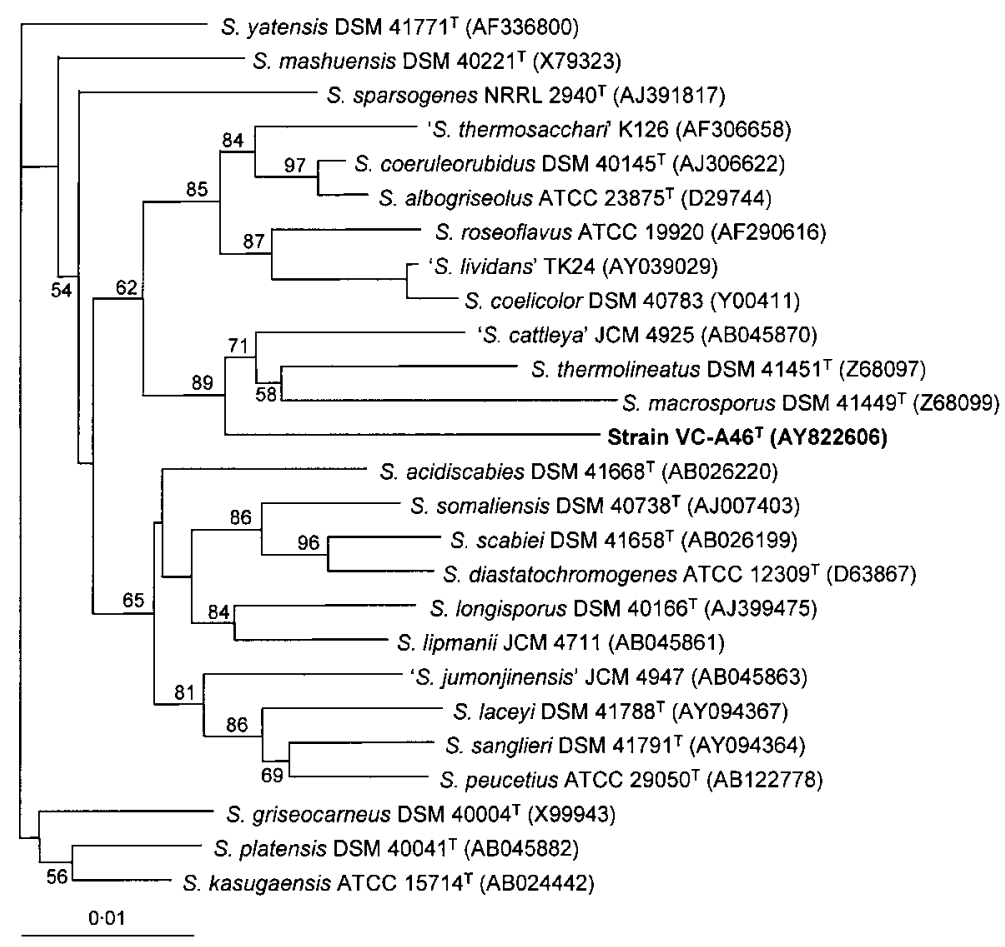

Fig. 1. Phylogenetic tree showing the relationship between strain $\mathrm{VC}-\mathrm{A} 46^{\top}$ and representative species of the genus Streptomyces based on nearly complete 16S rRNA gene sequences. Numbers at nodes indicate percentages of bootstrap support based on a neighbour-joining analysis (Saitou \& Nei, 1987) of 1000 sampled datasets. Only bootstrap values of more than $50 \%$ are shown. GenBank sequence accession numbers are given in parentheses. Bar, 0.01 substitutions per nucleotide position.

$41451^{\mathrm{T}}$ and $95.9 \%$ similarity (56/1354) to $S$. macrosporus DSM $41449^{\mathrm{T}}$. The position of strain VC-A $46^{\mathrm{T}}$ in the phylogenetic tree was unaffected by the choice of tree-making algorithm and the strains used as the outgroup. These results suggest that strain VC-A $46^{\mathrm{T}}$ represents a novel species that is closely related to the above three Streptomyces species.

The variable $\gamma$-region sequences (158-277 nt) of the $16 \mathrm{~S}$ rRNA gene from strain VC-A $46^{\mathrm{T}}$ and 245 Streptomyces species (only type strains were used) in GenBank were aligned (Supplementary Fig. S2 in IJSEM Online). Analysis of $\gamma$-region sequences indicated that the strain $\mathrm{VC}-\mathrm{A} 46^{\mathrm{T}}$ was clustered with S. thermolineatus DSM $41451^{\mathrm{T}}$, S. macrosporus DSM $41449^{\mathrm{T}}$ and S. megasporus DSM $41476^{\mathrm{T}}$; sequence similarity values were respectively $94 \cdot 4,91 \cdot 2$ and $89 \cdot 6 \%$. Strain VC-A $46^{\mathrm{T}}$ also had some phenotypic differences from these recognized Streptomyces species in the same branch. Thus, phylogenetic study supports the placement of strain $\mathrm{VC}-\mathrm{A} 46^{\mathrm{T}}$ in a novel species.

Levels of DNA-DNA relatedness between strain VC-A $46^{\mathrm{T}}$ and four closely related species (based on the above phylogenetic data), S. thermolineatus DSM $41451^{\mathrm{T}}$, 'S. cattleya' JCM 4925, S. macrosporus DSM $41449^{\mathrm{T}}$ and $S$. acidiscabies ATCC $49003^{\mathrm{T}}$, were $21 \cdot 5,39 \cdot 8,19 \cdot 8$ and $60 \cdot 6 \%$, respectively (Supplementary Table S2 in IJSEM Online). DNA-DNA relatedness values below $80 \%$ have been recommended for the recognition of novel genomic species of Streptomyces (Labeda, 1993, 1996, 1998). The observed levels of DNA-DNA relatedness values demonstrate the genomic distinction of strain $\mathrm{VC}-\mathrm{A} 46^{\mathrm{T}}$ from $S$. thermolineatus, 'S. cattleya', S. macrosporus and S. acidiscabies.

\section{Description of Streptomyces cheonanensis sp. nov.}

Streptomyces cheonanensis (che.on.an.en'sis N.L. masc. adj. cheonanensis pertaining to Cheonan, Republic of Korea, the geographical origin of the type strain).

Aerobic, Gram-positive, non-motile actinomycete that forms extensively branched aerial and substrate hyphae. Short or long, straight to flexuous chains of smoothsurfaced spores are evident on the aerial hyphae. The aerial mycelium is grey to white in colour and the substrate mycelium appears light yellow when grown on ISP 4 agar. The cell wall contains LL-diaminopimelic acid. Predominant cellular fatty acids are 14-methylpentadecanoic acid (iso$\left.\mathrm{C}_{16: 0} ; 47 \cdot 82 \%\right)$, hexadecanoic acid $\left(\mathrm{C}_{16: 0} ; 14 \cdot 44 \%\right)$ and cis9-hexadecenoic acid $\left(\mathrm{C}_{16: 1}\right.$ cis $\left.9 ; 10 \cdot 24 \%\right)$. The $\mathrm{G}+\mathrm{C}$ content of the genomic DNA is $75.5 \mathrm{~mol} \%$. Optimum growth occurs at $29^{\circ} \mathrm{C}$. Grows well in yeast extract $/ \mathrm{malt}$ extract broth adjusted to $\mathrm{pH} 6 \cdot 5-8 \cdot 0$. Tolerates $\mathrm{NaCl}$ concentrations up to $7 \%$. Aerial and substrate mycelia grow abundantly on both ISP 3 agar and Bennett's agar. Soluble pigments are generated on ISP 2, ISP 3, ISP 5 (glycerol/asparagine agar) and ISP 7. Capable of utilizing several carbon sources, including adonitol, arabinose, dextran, fructose, myo-inositol, mannitol, D-melezitose, Dmelibiose, raffinose, L-rhamnose, sucrose, xylitol and xylose. Can also use several nitrogen sources: $\mathrm{DL}-\alpha$-amino-n-butyric acid, L-cysteine, L-histidine, L-hydroxyproline, L-phenylalanine and L-valine. Resistant to penicillin G, but sensitive to neomycin, oleandomycin and rifampicin. Secretes compounds that inhibit mycelial growth of plant-pathogenic 
fungi including Alternaria mali, Colletotrichum orbiculare, Magnaporthe grisea, Fusarium oxysporum f. sp. lycopersici and Rhizoctonia solani and the oomycete Phytophthora capsici.

The type strain is strain VC-A46 ${ }^{\mathrm{T}} \quad(=\mathrm{KCCM}$ $42119^{\mathrm{T}}=$ NBRC $\left.100940^{\mathrm{T}}\right)$, isolated from a soil sample collected from Cheonan, Korea.

\section{Acknowledgements}

This study was supported by a grant from the Center for Plant Molecular Genetics and Breeding Research, Seoul National University and a grant (CG 1432) from the Crop Functional Genomics Center of the 21st Century Frontier Research Program funded by the Ministry of Science and Technology, Korea. We thank Michael Rabba for critically reviewing the manuscript.

\section{References}

Altschul, S. F., Madden, T. L., Schaffer, A. A., Zhang, J., Zhang, Z., Miller, W. \& Lipman, D. J. (1997). Gapped BLAST and PSI-BLAST: a new generation of protein database search programs. Nucleic Acids Res 25, 3389-3402.

Becker, B., Lechevalier, M. P. \& Lechevalier, H. A. (1965). Chemical composition of cell-wall preparations from strains of various formgenera of aerobic actinomycetes. Appl Microbiol 13, 236-243.

Chun, J. S., Youn, H. D., Yim, Y. I., Lee, H. K., Kim, M. Y., Hah, Y. C. \& Kang, S. O. (1997). Streptomyces seoulensis sp. nov. Int J Syst Bacteriol 47, 492-498.

Chung, Y. R., Sung, K. C., Mo, H. K., Son, D. Y., Nam, J. S., Chun, J. S. \& Bae, K. S. (1999). Kitasatospora cheerisanensis sp. nov., a new species of the genus Kitasatospora that produces an antifungal agent. Int J Syst Bacteriol 49, 753-758.

Fitch, W. M. (1971). Towards defining the course of evolution: minimum change for a specific tree topology. Syst Zool 20, 406-416.

Guckert, J. B., Ringelberg, D. B., White, D. C., Hanson, R. S. \& Bratina, B. J. (1991). Membrane fatty acids as phenotypic markers in the polyphasic taxonomy of methylotrophs within the Proteobacteria. J Gen Microbiol 137, 2631-2641.

Johnson, J. L. (1985). Determination of DNA base composition. Methods Microbiol 18, 1-31.

Kim, B. S. \& Hwang, B. K. (2003). Biofungicides. In Fungal Biotechnology in Agricultural, Food and Environmental Applications, pp. 123-133. Edited by D. K. Arora. New York: Marcel Dekker.

Labeda, D. P. (1993). DNA relatedness among strains of the Streptomyces lavendulae phenotypic cluster group. Int J Syst Bacteriol 43, 822-825.

Labeda, D. P. (1996). DNA relatedness among verticil-forming Streptomyces species (formerly Streptoverticillium species). Int J Syst Bacteriol 46, 699-703.

Labeda, D. P. (1998). DNA relatedness among the Streptomyces fulvissimus and Streptomyces griseoviridis phenotypic cluster groups. Int J Syst Bacteriol 48, 829-832.
Lechevalier, M. P. \& Lechevalier, H. (1970). Chemical composition as a criterion in the classification of aerobic actinomycetes. Int J Syst Bacteriol 20, 435-443.

Lee, J. Y. \& Hwang, B. K. (2002). Diversity of antifungal actinomycetes in various vegetative soils of Korea. Can J Microbiol 48, 407-417.

Lee, J. Y., Lee, J. Y., Jung, H. W. \& Hwang, B. K. (2005). Streptomyces koyangensis sp. nov., a novel actinomycete that produces 4-phenyl-3butenoic acid. Int J Syst Evol Microbiol 55, 257-262.

Locci, R. (1989). Streptomycetes and related genera. In Bergey's Manual of Systematic Bacteriology, vol. 4, pp. 2451-2452. Edited by S. T. Williams, M. E. Sharpe \& J. G. Holt. Baltimore: Williams \& Wilkins.

Mandel, M., Igambi, L., Bergendahl, M. L., Dodson, M. L., Jr \& Scheltgen, E. (1970). Correlation of melting temperature and cesium chloride buoyant density of bacterial deoxyribonucleic acid. $J$ Bacteriol 101, 333-338.

Marmur, J. \& Doty, P. (1962). Determination of the base composition of deoxyribonucleic acid from its thermal denaturation temperature. J Mol Biol 5, 109-118.

Page, R. D. M. (1996). TreeView: an application to display phylogenetic trees on personal computers. Comput Appl Biosci 12, 357-358.

Pospiech, A. \& Neumann, B. (1995). A versatile quick-prep of genomic DNA from gram-positive bacteria. Trends Genet 11, 217-218.

Saitou, N. \& Nei, M. (1987). The neighbor-joining method: a new method for reconstructing phylogenetic trees. Mol Biol Evol 4, 406-425.

Shirling, E. B. \& Gottlieb, D. (1966). Methods for characterization of Streptomyces species. Int J Syst Bacteriol 16, 313-340.

Swofford, D. L. (2002). PAUP*. Phylogenetic Analysis Using Parsimony (* and Other Methods), version 4.0b10. Sunderland, MA: Sinauer Associates.

Tanaka, Y. T. \& Ōmura, S. (1993). Agroactive compounds of microbial origin. Annu Rev Microbiol 47, 57-87.

Thompson, J. D., Higgins, D. G. \& Gibson, T. J. (1994). CLUSTAL W: improving the sensitivity of progressive multiple sequence alignment through sequence weighting, position-specific gap penalties and weight matrix choice. Nucleic Acids Res 22, 4673-4680.

Waksman, A. S. \& Henrici, A. T. (1943). The nomenclature and classification of the actinomycetes. J Bacteriol 46, 337-341.

Weisburg, W. G., Barns, S. M., Pelletier, D. A. \& Lane, D. J. (1991). 16 S ribosomal DNA amplification for phylogenetic study. J Bacteriol 173, 697-703.

Williams, S. T. \& Davies, F. L. (1967). Use of scanning electron microscope for the examination of actinomycetes. J Gen Microbiol 48, 171-177.

Williams, S. T., Goodfellow, M., Alderson, G., Wellington, E. M. H., Sneath, P. H. A. \& Sackin, M. J. (1983). Numerical classification of Streptomyces and related genera. J Gen Microbiol 129, 1743-1813.

Wu, W., Welsh, M. J., Kaufman, P. B. \& Zhang, H. H. (1997). Subcloning of DNA fragments. In Methods in Gene Biotechnology, pp. 15-28. Boca Raton, FL: CRC Press. 